\title{
Hubungan TAPSE dengan GGT pada paasien gagal jantung kronik di Bagian Ilmu Penyakit Dalam RSUP Prof. Dr. R. D. Kandou Manado
}

\author{
${ }^{1}$ Alvionita Patandean \\ ${ }^{2}$ Frans E. Wantania \\ ${ }^{2}$ Luciana Rotty \\ ${ }^{1}$ Kandidat Skripsi Fakultas Kedokteran Universitas Sam Ratulangi Manado \\ ${ }^{2}$ Bagian Ilmu Penyakit Dalam Universitas Sam Ratulangi Manado \\ Email: alvionitapatandean@gmail.com
}

\begin{abstract}
Right ventricular dysfunction is associated with chronic heart failure prognosis. TAPSE is one of the right ventricular systolic function tests which is routinely performed and adds prognostic information in patients with chronic heart failure (CHF). Gamma-glutamyl transferase (GGT) is a liver enzyme used to assess hepatobiliary dysfunction with high sensitivity. GGT is related to the severity of CHF and right ventricular dysfunction. This study aimed to determine the relationship of TAPSE and GGT in patients with CHF. This was an observational analytical study with a cross sectional design, conducted to CHF patients at Internal Medicine Department of Prof. Dr. R. D. Kandou Hospital Manado. The results showed 25 samples, aged 30-79 years. There were more males than females. The bivariate analysis showed the value of $r=-0.212$ and $P=0.156$. Conclusion: There was no association between TAPSE and GGT in patients with chronic heart failure.
\end{abstract}

Keywords: CHF, TAPSE, GGT, right ventricular dysfunction

\begin{abstract}
Abstrak: Disfungsi ventrikel kanan berhubungan dengan prognosis jangka panjang gagal jantung. TAPSE merupakan salah satu pemeriksaan fungsi sistolik ventrikel kanan yang rutin dilakukan dan menambah informasi prognostik pada pasien gagal jantung kronik (CHF). Gamma-glutamyl transferase (GGT) merupakan enzim hati untuk menilai fungsi hepatobiliaris dengan sensitifitas tinggi. GGT berhubungan dengan beratnya CHF dan disfungsi ventrikel kanan. Penelitian ini bertujuan untuk mengetahui hubungan TAPSE dan GGT pada pasien gagal jantung kronik. Jenis penelitian ialah observasional analitik dengan desain potong lintang terhadap pasien gagal jantung kronik di Bagian Ilmu Penyakit Dalam RSUP Prof. R. D. Kandou Manado. Hasil penelitian mendapatkan 25 sampel, usia 30-79 tahun. Jenis kelamin laki-laki lebih banyak daripada perempuan. Hasil analisis bivariat menunjukkan nilai $\mathrm{r}=$ 0,212 dan nilai $P=0,156>0,05$. Simpulan: Tidak terdapat hubungan antara TAPSE dan GGT pada pasien gagal jantung kronik.
\end{abstract}

Kata kunci: gagal jantung kronik, TAPSE, GGT, disfungsi ventrikel kanan

Gagal jantung merupakan sindrom klinis yang ditandai oleh sesak napas dan fatik yang disebabkan oleh kelainan struktur atau fungsi jantung. Gagal jantung timbul karena terdapat remodeling progresif miokard akibat beban pada miokard. ${ }^{1}$

Kira-kira 26 juta orang dewasa di dunia yang hidup dengan gagal jantung. ${ }^{2}$ Berdasarkan Riset Kesehatan Dasar 2013, prevalensi gagal jantung dengan wawancara terdiagnosis dokter di Indonesia sebesar $0,13 \%$, dan yang terdiagnosis dokter atau gejala sebesar 0,3\%. Prevalensi gagal jantung berdasarkan terdiagnosis dokter tertinggi di DI Yogyakarta (0,25\%), disusul Jawa Timur (0,19\%), dan Jawa Tengah (0,18\%). Kejadian gagal jantung provinsi Sulawesi Utara dengan wawancara 
terdiagnosis berada pada urutan keempat dengan prevalensi sebesar $0,14 \%$, dan yang terdiagnosis dokter atau gejala sebesar $0,4 \%{ }^{3}$

Gamma-glutamyl transferase (GGT) merupakan tes fungsi enzimatik yang memiliki sensitifitas yang tinggi. GGT digunakan dalam praktik klinis untuk menilai fungsi sistem hepatobiliaris. ${ }^{4}$ Pada penelitian-penelitian sebelumnya GGT dihubungkan dengan risiko penyakit kardiovaskular, penyakit arteri koroner, infark miokard akut, diabetes melitus, hipertensi, dan sindrom metabolik. Konsentrasi GGT serum yang tinggi berhubungan beratnya gagal jantung kronik dan hasil jangka panjangnya. ${ }^{4-7}$ Parissis et al. ${ }^{5}$ menemukan GGT berhubungan dengan fungsi ventrikel kanan dan kiri. Peningkatan GGT >49 IU/L berhubungan dengan disfungsi ventrikel kanan secara signifikan $(P<0,001)$ pada pasien sindroma koroner akut. $^{7}$

Disfungsi sistolik ventrikel kanan berhubungan dengan prognosis jangka panjang yang buruk pada pasien gagal jantung. ${ }^{8,9}$ Salah satu pemeriksaan fungsi sistolik ventrikel kanan adalah pemeriksaan Tricuspid Anular Plane Systolic Excursion (TAPSE) yang dinilai dengan ekokardiografi. $^{10,11}$ TAPSE telah dibuktikan berhubungan dengan prognosis pasien gagal jantung kongestif sedang sampai berat. $^{8}$

Tujuan penelitian ini ialah untuk mengetahui hubungan TAPSE dan GGT pada pasien gagal jantung kronik.

\section{METODE PENELITIAN}

Jenis penelitian ini ialah observasional analitik dengan desain potong lintang. Penelitian ini dilakukan dari bulan November-Desember 2015 di Irina F dan Cardiovascular and Brain Center RSUP Prof. R. D. Kandou Manado.

Populasi penelitian ialah pasien gagal jantung kronik yang dirawat dengan kriteria inklusi gagal jantung kronik dan bersedia dijadikan sebagai subjek penelitian, sedangkan kriteria eksklusi yaitu pasien dengan penyakit sirosis hepatis, hepatitis $\mathrm{C}$, hepatitis $\mathrm{B}$, dan gagal jantung akut.

Pengambilan sampel dilakukan dengan cara consecutive sampling sebesar 25 sampel. Semua subyek penelitian menjalani proses pemeriksaan melalui anamnesis, pemeriksaan fisik standar, serta pemeriksaan penunjang yang menggunakan metode baku yang ada di laboratorium kesehatan. Setelah uji saring, dilakukan pemeriksaan ekokardiografi untuk mendapatkan nilai TAPSE dan pemeriksaan GGT serum dengan menggunakan sampel darah.

\section{HASIL PENELITIAN}

Dari 25 subjek penelitian terdapat 17 laki-laki dan 8 perempuan. Usia subjek penelitian berkisar 30-79 tahun, dengan rerata 60 tahun, median 61 tahun, dan standar deviasi 14,67.

Tekanan darah sistol berkisar 80-180, dengan rerata 117,20, median 110 dan standar deviasi 18,82. Tekanan darah diastol berkisar 50-90 dengan rerata73,60, median 80 dan standar deviasi 9,95.

TAPSE berkisar 1 - 2,8 cm dengan rerata $1,86 \mathrm{~cm}$, dan median $1,9 \mathrm{~cm}$. Untuk karakteristik GGT berkisar 11-180 U/L dengan rerata $56 \mathrm{U} / \mathrm{L}$, median $38 \mathrm{U} / \mathrm{L}$ dan standar deviasi 46,80 (Tabel 1).

Distribusi frekuensi sampel berdasarkan tekanan darah, tekanan darah sistol frekuensi terbesar $<120$ dan frekuensi terkecil tekanan darah sistol >160( (Tabel 2), sedangkan untuk tekanan darah diastol, dari sampel hanya terdapat rentang $<80$ dan 80-89, dengan frekuensi paling banyak pada tekanan darah diastol <80 (Tabel 3).

Kelompok responden terbesar terdapat pada kelas NYHA II dengan persentase $48 \%$, sedangkan kelompok responden terkecil pada kelas NYHA IV dengan presentase $16 \%$ (Tabel 4).

Penyebab gagal jantung kronik terbanyak yaitu CAD dengan presentasi 32\%, HHD dan VHD penyebab paling sedikit dengan persentase 4\% (Tabel 5). 
Tabel 1. Karakteristik Umum Sampel Penelitian

\begin{tabular}{ccccccc}
\hline & N & $\begin{array}{c}\text { Nilai } \\
\text { Minimum }\end{array}$ & $\begin{array}{c}\text { Nilai } \\
\text { Maksimum }\end{array}$ & Mean & Median & $\begin{array}{c}\text { Standar } \\
\text { Deviasi }\end{array}$ \\
\hline Umur & 25 & 30 & 79 & 60 & 61 & 14,67 \\
TDS & 25 & 80 & 160 & 117,20 & 110 & 18,82 \\
TDD & 25 & 50 & 90 & 73,60 & 80 & 9,95 \\
TAPSE (cm) & 25 & 1 & 2,8 & 1,86 & 1,9 &, 46 \\
GGT (IU/L) & 25 & 11 & 180 & 56,00 & 38 & 46,80 \\
\hline
\end{tabular}

Tabel 2. Distribusi frekuensi sampel berdasarkan tekanan darah sistol

\begin{tabular}{ccc}
\hline TDS & Frekuensi & $(\%)$ \\
\hline$<120$ & 17 & 68 \\
$120-139$ & 4 & 16 \\
$140-159$ & 3 & 12 \\
$>160$ & 1 & 4 \\
Total & 25 & 100 \\
\hline
\end{tabular}

Tabel 3. Distribusi frekuensi sampel berdasarkan tekanan darah diastol

\begin{tabular}{ccc}
\hline TDD & Frekuensi & $(\%)$ \\
\hline$<80$ & 23 & 92 \\
$80-89$ & 2 & 8 \\
$90-99$ & 0 & 0 \\
$>100$ & 0 & 0 \\
Total & 25 & 100 \\
\hline
\end{tabular}

Tabel 4. Karakteristik sampel berdasarkan kelas NYHA

\begin{tabular}{ccc}
\hline Kelas NYHA & Frekuensi & $(\%)$ \\
\hline II & 12 & 48 \\
III & 9 & 36 \\
IV & 4 & 16 \\
Total & 25 & 100 \\
\hline
\end{tabular}

Hasil uji kenormalan data TAPSE dan GGT dengan uji Kolmogorov-Smirnov menyatakan data TAPSE menyebar normal $($ Sig $=0,200>\alpha=0,05)$ dan data GGT tidak menyebar normal ( $\mathrm{Sig}=0,008<\alpha=$ $0,05)$. Oleh sebab itu hubungan kedua variabel diuji dengan koefisien korelasi Spearman. Hasil uji ini mendapatkan $r_{\mathrm{s}}=$ 0,212 dengan $\mathrm{p}=0,155$ (Tabel 6). Hasil korelasi ini menyatakan hubungan negatif antara TAPSE dan GGT, namun secara statistik tidak bermakna. Hubungan kedua variabel dalam bentuk data rank dapat dilihat pada Gambar 1.

Tabel 5. Karakteristik sampel berdasarkan penyebab gagal jantung kronik

\begin{tabular}{lcc}
\hline Penyebab & Jumlah n (25) & $(\%)$ \\
\hline CAD & 8 & 32 \\
CAD,HHD & 6 & 24 \\
HHD & 5 & 20 \\
HHD,VHD & 1 & 4 \\
VHD & 5 & 20 \\
\hline CAD, Coronary & Artery Disease; & HHD, \\
Hypertension Heart Disease; VHD, Valvular Heart \\
Disease.
\end{tabular}

Tabel 6. Hubungan TAPSE dan GGT

\begin{tabular}{cccc}
\hline Variabel 1 & Variabel 2 & r & p \\
\hline TAPSE & GGT & $-0,212$ & 0,156 \\
\hline
\end{tabular}

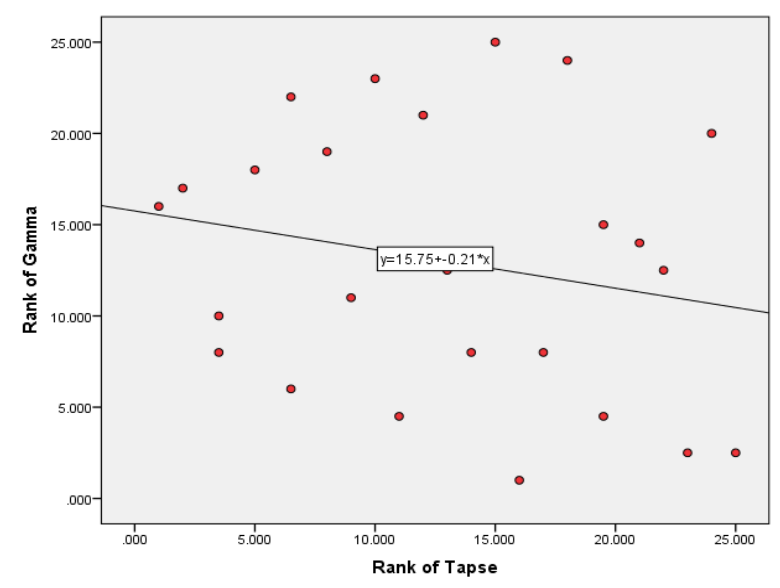

Gambar 1. Scatterplot hubungan data rank TAPSE dengan data rank $\gamma$-GT

\section{BAHASAN}

Hasil analisis hubungan TAPSE dan GGT pada pasien gagal jantung kronik menunjukkan hubungan negatif $(\mathrm{r}=$ 0,212 ) artinya semakin menurun nilai 
TAPSE, GGT semakin meningkat. Namun, secara statistik tidak bermakna $(p=0,155)$. Dapat disimpulkan TAPSE tidak mempengaruhi kadar GGT.

Tricuspid annular plane systolic excursion (TAPSE) merupakan salah satu pemeriksaan untuk menilai fungsi sistolik ventrikel kanan dan telah dibuktikan sebagai prediktor prognosis gagal jantung. Penurunan TAPSE pada pasien dengan tekanan pulmoner yang tinggi menyebabkan disfungsi ventrikel kanan yang berat. ${ }^{12,13}$ Disfungsi ventrikel kanan berhubungan dengan kongesti hati berat karena peningkatan tekanan vena sentral yang dapat menyebabkan peningkatan enzim hati. ${ }^{14}$

Salah satu penyebab gagal jantung kanan ialah regurgitasi trikuspid (TR). TR rawan mengakibatkan kongesti pasif karena tekanan ditransmisikan langsung ke pembuluh darah hati dan sinusoid. ${ }^{15}$ Peningkatan tekanan vena akibat disfungsi ventrikel kanan menyebabkan atrofi hepatosit dan edema perisinusoid yang dapat mengganggu difusi oksigen dan nutrisi ke hepatosit. Akibat kongeti hati ini ikterus ringan, kelainan enzim hati dan penurunan metabolisme obat. ${ }^{14}$ Tingginya tes fungsi hati kolestatik (alkalin fosfatase, GGT, bilirubin) berhubungan secara bermakna dengan ketidakmampuan trikuspid pada pasien gagal jantung. ${ }^{16}$ Penelitian pada hipertensi arteri pulmoner ditemukan hubungan terbalik antara TAPSE dengan tingkat TR, yang artinya sama dengan fungsi ventrikel buruk dan TR semakin besar. ${ }^{17}$ Berbeda dengan hasil penelitian Kjaergaard et al. ${ }^{18}$ ditemukan tidak ada hubungan antara TAPSE dan gradien tekanan TR maksimal. ${ }^{18}$

Penelitian sebelumnya memperlihatkan peningkatan fungsi hati dengan penurunan CI (cardiac index) dan peningkatan CVP (central venous pressure). Hampir semua dari parameter fungsi hati berhubungan dengan peningkatan CVP, khususnya peningkatan GGT dan bilirubin direk, hanya aspartat transaminase (AST), alanin transaminase (ALT), dan bilirubin total yang berhubungan dengan penurunan $\mathrm{CI}$.
Dari penemuan ini diperlihatkan patofisiologi abnormalitas fungsi hati pada gagal jantung merupakan kombinasi kongesti dan penurunan cardiac output. ${ }^{14,19}$

Peningkatan GGT umum terjadi pada pasien gagal jantung kronik. Poezl et al. ${ }^{6}$ berspekulasi bahwa GGT mungkin berguna pada stratifikasi risiko pada gagal jantung kronik. GGT mungkin muncul sebagai penanda baru pada gagal jantung kronik yang stabil. Namun, perlu ditekankan GGT bukan spesifik jantung, sehingga tidak bisa digunakan untuk diagnosis gagal jantung. ${ }^{6}$

Pada penelitian Sarikaya et al. $^{7}$ peningkatan GGT >49 IU/L pada disfungsi ventrikel kanan pada pasien gagal jantung dengan sindrom koroner akut dengan disfungsi ventrikel kiri, ditemukan bermakna pada pada analisis univariat. Disfungsi ventrikel kanan di sini didefinisikan sebagai dilatasi ventrikel kanan dikombinasikan dengan tanda McConnel. Juga pada pemeriksaan ekokardiografi, disfungsi ventrikel kanan, regurgitasi mitral dan TR sedang sampai berat lebih sering ditemukan pada kelompok dengan peningkatan GGT serum. ${ }^{7}$ Pada penelitian ini tidak ditemukan hubungan bermakna antara disfungsi ventrikel kanan yang dinilai lewat pemeriksaan TAPSE dengan GGT pada pasien gagal jantung kronik karena ekslusi subyek penelitian dengan gangguan kolestasis. Keterbatasan penelitian ini ialah dalam penilaian disfungsi ventrikel hanya terbatas pada TAPSE dan jumlah sampel yang diteliti sedikit.

\section{SIMPULAN}

Berdasarkan hasil penelitian dan bahasan maka dapat disimpulkan bahwa tidak terdapat hubungan antara TAPSE dengan GGT pada pasien gagal jantung kronik.

\section{SARAN}

Perlu dilakukan penelitian lanjut mengenai TAPSE dan GGT dalam jumlah sampel yang lebih banyak dan cakupan lebih luas; juga penilaian fungsi ventrikel tidak terbatas pada satu pemeriksaan. 


\section{DAFTAR PUSTAKA}

1. Pangabean MM. Gagal Jantung. Dalam: Setiati S, Alwi I, Sudoyo W, Simadibrata M, Setyohadi B, Syam AF, editors. Ilmu penyakit dalam (4th ed). Jakarta: Internal Publishing, 2014; p. 1132-5.

2. Ponikowski P, Anker SD, AlHabib KF, Cowie MR, Force TL, Hu S, et al. Heart failure: Preventing disease and death worldwide. European Society of Cardiology. 2014:4-9.

3. Laporan Nasional 2013. Riset kesehatan dasar (RISKESDAS) 2013. Badan penelitan dan pengembagan kesehatan. Departemen Kesehatan, Republik Indonesia, Jakarta, Desember 2013.

4. Haurissa AE. Gamma-glutamyltransferase sebagai biomarker risiko penyakit kardiovaskuler. Cermin Dunia Kedokteran. 2014;41:816-8.

5. Parissis JT, Farmakis D, Andreoli C, Stergiou PR, Ambrosio G, Nana MA, et al. Cardio-reno-hepatic interactions in acute heart failure : The role of $\gamma$-glutamyl transferase. Int J Cardio. 2014. Letter to editor.

6. Poelzl G, Eberl C, Achrainer H, Doerler J, Pachinger $O$, Frick $M$, et al. Prevalence and prognostic significance of elevated $\gamma$-glutamyl transferase in chronic heart failure. Circ Heart Fail. 2009;2:294-302.

7. Sarikaya S, Aydin G, Yucel H, Kaya H, Yildirimli K, Basaran A, et al. Usefulness of admission gammaglutamyltransferase level for predicting new-onset heart failure in patients with acute coronary syndrome with left ventricular systolic dysfunction. Arch Turk Soc Cardiol. 2014;42:236-44.

8. Ghio S, Gavassi A, Campana C, Inserra C, Klersy C, Sebastiani R, et al. Independent and addictive prognostic value of right ventricular systolic function and pulmonary artery pressure in patients with chronic heart failure. $\mathrm{J}$ Am Coll Cardiol 2001:37(1):183-8.

9. Di Salvo TG. Mathier M, Semigran MJ. Dec GW. Preserved right ventricular ejection fraction predicts exercise capacity and survival in advanced heart failure. J Am Cool Cardiol 1995;251143-53.

10. Soesanto AM. Pemeriksaan hemodinamik ekokardiografi pada kasus kegawatan dan kritikal jantung seri III: Penilaian hemodinamik jantung kanan. J Kardiol Indones. 2013;34:55-9.

11. Bleeker GB, Steendijk P, Holman ER, Yu CM, Breithhardt OA, Koandorp TAM, et al. Assessing right ventricular function: the role of echocardiography and complementary technologies. Heart. 2006;92:i19-i26.

12. Rudski LG, Lai WW, Afilalo J, Hua L, Handschumacher MD, Chandrasekaren $\mathrm{K}$, et al. Guidelines for the echocardiographic assessment of the right heart in adults: a report from the American Society of Echocardiography. J Am Soc Echocardiogr. 2010;23:685-713.

13. Ghio S, Recusani F, Klersy C, Sebastiani R, Laudisa ML. Campana C, et al. Prognostic usefulness of tricuspid annular plane systolic excursion in patiets with congestive heart failure secondary to idiopatic or ischemic dilated cardiomyopathy. Am J Cardiol. 2000;1:837-42.

14. Alvarez AM, Mukherjee D. Liver abnormalities in cardiac diseases and heart failure. Int $\mathrm{J}$ Angio. 2011;20:135-42.

15. Sherlock $\mathbf{S}$. The liver in heart failure; relation of anatomical, functional, and circulatory changes. $\mathrm{Br}$ Heart J. 1951;13:273-293.

16. Lau GT, Tan HC, Kritharides L. Type of liver dysfunction in heart failure and its relation to severity of tricuspid regurgitation. Am J Cardiol. 2002;90:1405-9.

17. Forfia PR, Fisher MR, Mathai SC, Housten-Harris T, Hemnes AR, Borlaug BA, et al. Trikuspid annular displacement predicts survival in pulmonary hypertension. Am J Respir Crit Care Med, 2006;174:1034-41.

18. Kjaergaard J, Akkan D, Iversen KK, Kober L, Torp-Pedersen C, Hassager C. Right ventricular dysfunction as an independent predictor of short and long term mortality in patients with heart failure. Eur J Heart Fail. 2007;9:610-6. 
Patandean, Wantania, Rotty: Hubungan TAPSE dengan...

19. Van Deursen VM, Damman K, Hillege

HL, van Beek AP, van Veldhuisen

DJ, Voors AA. Abnormal liver function in relation to hemodynamic profile in heart failure patients. J Card Fail. 2010;16:84-89. 